Case Report

\title{
A Case of Invasive Sinonasal Carcinosarcoma: The Importance of Early Detection
}

\author{
Jason Yuen $\mathbb{D}^{1},{ }^{1}$ Vinay Varadarajan, ${ }^{2}$ Marios Stavrakas ${ }^{D},{ }^{2}$ Samiul Muquit, ${ }^{1}$ \\ and Hisham Khalil $\mathbb{1}^{2}$ \\ ${ }^{1}$ South West Neurosurgery Centre, Derriford Hospital, Plymouth PL6 8DH, UK \\ ${ }^{2}$ Department of Ear, Nose and Throat, Derriford Hospital, Plymouth PL6 8DH, UK
}

Correspondence should be addressed to Hisham Khalil; hisham.khalil@plymouth.ac.uk

Received 20 February 2018; Accepted 19 March 2018; Published 22 April 2018

Academic Editor: Kamal Morshed

Copyright (c) 2018 Jason Yuen et al. This is an open access article distributed under the Creative Commons Attribution License, which permits unrestricted use, distribution, and reproduction in any medium, provided the original work is properly cited.

Sinonasal carcinosarcomas represent rare neoplasms, with aggressive character and unfavourable prognosis. We present a case of extensive sinonasal carcinosarcoma extending into the anterior cranial fossa and into the orbit and also a review of the current international literature regarding this rare yet aggressive neoplasm. There is currently a lack of specific guidelines on the optimal management of sinonasal carcinosarcoma and the treatment represents a challenge for the clinician. The key message that we would like to disseminate to our colleagues is the importance of suspicion and early detection, as well as the necessity to adopt a holistic approach when counselling patients.

\section{Introduction}

A malignant biphasic neoplasm consisting of an epithelial (squamous) element and mesenchymal component is known as a carcinosarcoma (also known as pleomorphic carcinoma, spindle cell carcinoma, pseudosarcoma, and pseudosarcomatous squamous cell carcinoma) $[1,2]$ although the exact nomenclature and subclassifications are variable [3]. It is classified under squamous cell carcinoma by the World Health Organization (WHO) [4].

Carcinosarcoma may arise from any squamous epithelium (e.g., salivary glands, respiratory tract, upper aerodigestive tract, and female reproductive organs) [5], but its occurrence in the sinonasal region is extremely rare [1]. There is very little evidence available about its best management.

\section{Case Presentation}

A 75-year-old gentleman first presented to primary care with a three month history of left-sided headaches and diplopia. He also complained of altered taste sensation and paraesthesia in the left maxillary region. There was no history of epistaxis. The patient attended his general practitioner on multiple occasions and was given sinusitis treatment until a CT scan was finally performed due to persistence of symptoms, upon which the patient was then referred to the ENT service.

He has a background history of fast atrial flutter (on bisoprolol), hypertension, polymyalgia rheumatica, benign prostatic hyperplasia, and previously excised papillary squamous cell carcinoma in the left thigh. He quit smoking 40 years prior to presentation. Otherwise, he had lived independently with WHO performance status of 1 (Karnofsky status 90).

The patient underwent complete head and neck examination including flexible nasoendoscopy. There was no discreet neck lymphadenopathy. Nasoendoscopy revealed a mass down to the left inferior turbinate obscuring the left nasal cavity. He complained of diplopia on the left side on the lateral gaze with proptosis of approximately $3 \mathrm{~mm}$ compared to the contralateral side. Vision was $6 / 30$ bilaterally with glasses. There was no relative afferent pupillary defect or papilloedema. 
2.1. Investigations. Initial CT scan revealed an aggressive lesion in left ethmoidal and frontal sinuses, invading the left orbit and anterior cranial fossa. CT neck and thorax showed no cervical or chest lymphadenopathy.

Subsequent MRI imaging also showed evidence of bone erosion with breaching of the dura in the vicinity of the left orbitofrontal cortex although there was no signal change in the brain to suggest brain invasion (Figure 1). There was destruction of left lamina papyracea. An incidental right anterior cranial fossa meningioma, distant from sinonasal lesion was also identified. This pathologic finding did not have any significant clinical relevance with the primary disease.

A staged whole body positron-emission tomography (PET) scan showed no other distant lesions but confirmed lesion progression through the frontal sinus.

Our initial differential diagnoses were squamous cell carcinoma, carcinosarcoma, lymphoma, teratocarcinosarcoma, olfactory neuroblastoma, small cell carcinoma and alveolar rhabdomyosarcoma.

2.2. Treatment. After the diagnostic workup, the patient underwent endoscopic examination of the nose and biopsy of the lesion under general anaesthesia. Extensive disease was noted at the ipsilateral maxillary antrum. Histology revealed an extensive necrotic biphasic epithelioid, spindled malignant neoplasm in keeping with carcinosarcoma. Immunohistochemistry afterwards showed no loss of DNA mismatch repair (MMR) protein expression.

2.3. Outcome. After a successful biopsy and radiological investigative workup, the patient was discharged home. Unfortunately in the community, his preexisting comorbidities worsened, and he developed poorly controlled fast atrial flutter and urosepsis with E. Coli bacteraemia. He was readmitted for antimicrobial and supportive treatment. The patient eventually recovered and was discharged.

Discussion was undertaken at the multidisciplinary meeting and with international experts in the field. The consensus is that although the disease can potentially be resected with major surgery such as craniofacial resection, due to its location and size, surgical treatment would have significant risk of bleeding, cerebrospinal fluid (CSF) leak, and meningitis. After detailed consultation and discussion about the possible treatment options including the risks of such procedures with the patient and his family, he was not keen to proceed and opted for palliative radiotherapy and symptomatic management.

The radiotherapy dose delivered was $20 \mathrm{~Gy}$ in five days, then a two-week break and finally another $20 \mathrm{~Gy}$ in five days. One year after diagnosis, patient tolerated the radiotherapy and continued to lead an independent life.

\section{Discussion}

In the head and neck area, carcinosarcomas most frequently occur in the larynx and oral cavity, followed by the skin, tonsils, sinonasal tract, pharynx and hypopharynx $[6,7]$. Histologically, they have been classified as part of a spectrum

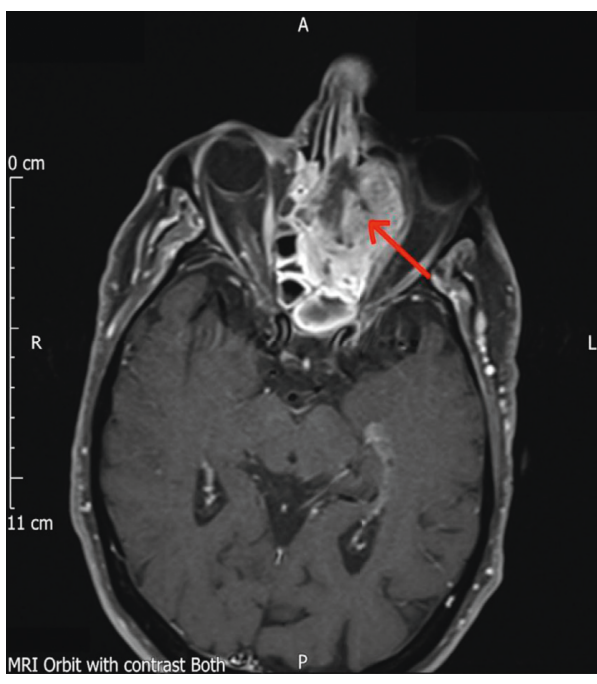

(a)

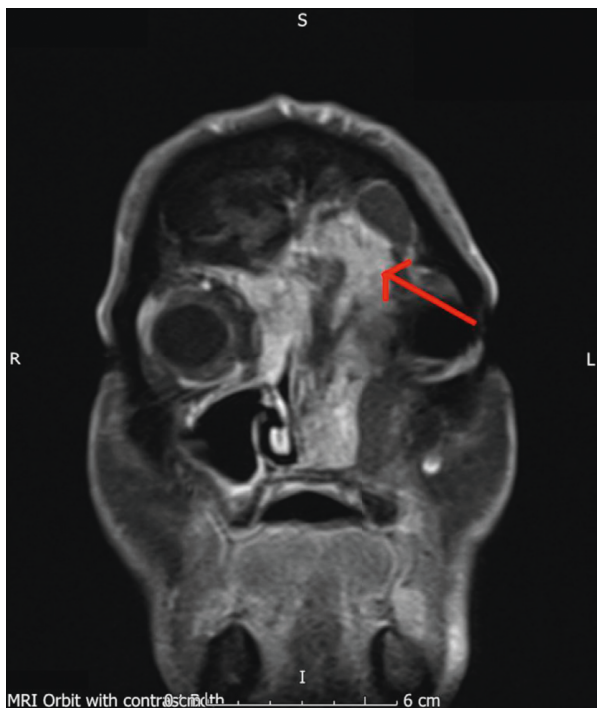

(b)

FIgURE 1: MRI head scan shows breaching of dura mater. Red arrow denotes lesion of interest. (a) Axial slide. (b) Coronal slide.

of sarcomatoid carcinomas, most of which present in late middle-aged men with a long history of tobacco use. They consist of foci of overt carcinoma admixed with areas of divergent differentiation into mesenchymal tissues [8]. Spindle cell formation is also typical in the sarcomatous component. A recent study suggested that a MET protooncogene mutation may be a prerequisite event in its pathogenesis [9].

Presenting symptoms of sinonasal carcinosarcomas typically include nasal obstruction, epistaxis, facial pain, and headache $[10,11]$. These are rather nonspecific to the disease. They tend to grow rapidly, with extensive local destruction. Therefore, early diagnosis and aggressive therapy are necessary to improve the often dismal prognosis $[2,8]$.

In a Japanese case report of maxillary carcinosarcoma, the patient died despite intensive radiochemotherapy and total maxillectomy due to rapid tumour recurrence and metastasis. However, it appeared the carinomatous component 
TABLE 1: Cases of sinonasal carcinosarcoma that are reported in the literature.

\begin{tabular}{|c|c|c|c|c|c|c|}
\hline Number & Age (years)/sex & Location & Stage & Treatment & Outcome & Author, year \\
\hline 1 & $62 / \mathrm{F}$ & Maxillary sinus & ND & RT & $\begin{array}{l}\text { No marked } \\
\text { improvement of the } \\
\text { tumor, DWD }\end{array}$ & $\begin{array}{c}\text { Meyer and } \\
\text { Shklar, } 1957 \\
{[24]}\end{array}$ \\
\hline 2 & $71 / \mathrm{M}$ & $\begin{array}{l}\text { Maxillary + ethmoid } \\
\text { sinuses }\end{array}$ & T4aN0M0 & $\begin{array}{c}\text { Preoperative } \mathrm{RT}+\mathrm{TM} \\
+\mathrm{RE}\end{array}$ & $\begin{array}{l}\text { ND about postoperative } \\
\text { tumor condition, death } \\
\text { due to intracerebral } \\
\text { abscess at postoperative } \\
\text { period }\end{array}$ & $\begin{array}{l}\text { Feinmesser } \\
\text { et al., } 1982 \text { [16] }\end{array}$ \\
\hline 3 & $65 / \mathrm{F}$ & Maxillary sinus & ND & $\mathrm{TM}+\mathrm{RT}$ & $\begin{array}{l}\text { LR, DWD } 8 \text { months } \\
\text { later }\end{array}$ & $\begin{array}{l}\text { Ampil, } 1985 \\
{[14]}\end{array}$ \\
\hline 4 & $\begin{array}{c}57 / \mathrm{F} \\
\text { (postradiation) }\end{array}$ & Nasoethmoid sinus & ND & $\begin{array}{l}\text { Tumor excision, } \\
\text { ethmoidectomy and } \\
\text { turbinectomy }\end{array}$ & $\begin{array}{l}\text { LR } 5 \text { months after } \\
\text { surgery, outcome } \\
\text { uncertain }\end{array}$ & $\begin{array}{c}\text { Hafiz et al., } \\
1987 \text { [17] }\end{array}$ \\
\hline 5 & $60 / \mathrm{M}$ & Nasomaxillary sinus & T3N0M0 & $\mathrm{TM}+\mathrm{RT}+\mathrm{CT}$ & $\begin{array}{l}\text { LR, DWD } 2 \text { months } \\
\text { later (diffuse metastasis } \\
\text { in lung and brain) }\end{array}$ & $\begin{array}{c}\text { Sonobe, } 1989 \\
{[11]}\end{array}$ \\
\hline 6 & $53 / \mathrm{M}$ & $\begin{array}{l}\text { Maxillary + ethmoid } \\
\text { sinuses }\end{array}$ & T4aN0M0 & $\begin{array}{l}\mathrm{TM}+\text { craniofacial } \\
\text { resection + } \mathrm{RT}+\mathrm{CT}\end{array}$ & $\begin{array}{c}\text { Disease free after } 9 \\
\text { months }\end{array}$ & $\begin{array}{l}\text { Shindo et al., } \\
1990 \text { [2] }\end{array}$ \\
\hline 7 & $81 / \mathrm{F}$ & Maxillary sinus & T3N0M0 & $\begin{array}{l}\mathrm{TM}+\mathrm{RT}+2 \mathrm{nd} \\
\text { operation }\end{array}$ & $\begin{array}{l}\text { LR, DWD } 3 \text { months } \\
\text { after second operation }\end{array}$ & $\begin{array}{l}\text { Sanabre et al., } \\
1998 \text { [27] }\end{array}$ \\
\hline 8 & $47 / \mathrm{M}$ & Maxillary sinus & ND & $\mathrm{PM}+\mathrm{RT}$ & LR, DWD after 1 year & $\begin{array}{l}\text { Furuta et al., } \\
2001[10]\end{array}$ \\
\hline 9 & $54 / \mathrm{M}$ & Maxillary sinus & T3N3M0 & $\mathrm{RT}+\mathrm{CT}$ & $\begin{array}{l}\text { DWD } 4 \text { months; } \\
\text { possibly from lung } \\
\text { metastasis }\end{array}$ & $\begin{array}{l}\text { Howard et al., } \\
2007 \text { [19] }\end{array}$ \\
\hline $\begin{array}{l}10 \text { case } \\
\text { series }(19 \\
\text { cases })\end{array}$ & $\begin{array}{c}\text { Mean age at } \\
\text { diagnosis } 54 \\
\text { (range, } 42-66) \\
\text { Male } 11 \\
\text { Female } 8\end{array}$ & $\begin{array}{c}\text { Sinonasal track, } \\
\text { unclear exact locations }\end{array}$ & $\begin{array}{c}\text { T1/2 } 3 \\
\text { T3/4 } 16 \\
\text { N0 } 19 \\
\text { M0 } 19\end{array}$ & $\begin{array}{c}\text { Surgery alone } 2 \\
\text { Surgery and RT } \\
7, \text { RT alone } 2 \\
\text { CT + RT } 2\end{array}$ & $\begin{array}{c}\text { Mean follow-up } 38 \\
\text { months }(6-40) \\
5 \text { with disease at last } \\
\text { follow-up } \\
0 \text { death at follow-up }\end{array}$ & $\begin{array}{c}\text { Doshi et al., } \\
2010 \text { [15] }\end{array}$ \\
\hline 11 & $75 / \mathrm{M}$ & Nasal cavity & T4N0M0 & Surgery + CT + RT & $\begin{array}{c}\text { Disease-free after } 5 \\
\text { years }\end{array}$ & $\begin{array}{l}\text { Terada and } \\
\text { Kawasaki, } \\
2011[30]\end{array}$ \\
\hline 12 & $60 / \mathrm{M}$ & $\begin{array}{l}\text { Maxillary sinus and } \\
\text { nasal cavity }\end{array}$ & Unclear & $\mathrm{CT}+\mathrm{RT}$ & DWD after 9 months & $\begin{array}{c}\text { Terada, } 2011 \\
\text { [29] }\end{array}$ \\
\hline 13 & $29 / \mathrm{F}$ & Nasopharyngeal & $\mathrm{T} 1 \mathrm{~N} 2 \mathrm{cM} 0$ & RT & $\begin{array}{c}\text { Clinically free-of- } \\
\text { disease } 2 \text { months after } \\
\text { RT }\end{array}$ & $\begin{array}{c}\text { Lim et al., } 2012 \\
\text { [22] }\end{array}$ \\
\hline 14 & $60 / \mathrm{M}$ & $\begin{array}{l}\text { Maxillary + ethmoid } \\
\text { sinuses }\end{array}$ & T3N0M0 & $\mathrm{TM}+\mathrm{RT}+\mathrm{CT}$ & LR, FL & $\begin{array}{c}\text { Moon, } 2013 \\
{[1]}\end{array}$ \\
\hline 15 & $29 / \mathrm{M}$ & Nasal cavity & T2N0M0 & Surgery & $\begin{array}{c}\text { Disease-free after } 6 \\
\text { months }\end{array}$ & $\begin{array}{c}\text { Gupta, } 2013 \\
{[32]}\end{array}$ \\
\hline 16 & $52 / \mathrm{M}$ & $\begin{array}{l}\text { Frontal, sphenoid, } \\
\text { ethmoid, and maxillary } \\
\text { sinuses }\end{array}$ & T4aN0M0 & $\mathrm{TM}+\mathrm{RT}+\mathrm{CT}$ & 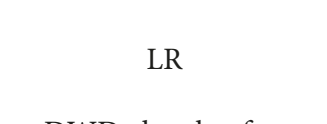 & $\begin{array}{c}\text { Alem and } \\
\text { AlNoury, } 2014 \\
{[13]}\end{array}$ \\
\hline 17 & $61 / \mathrm{M}$ & Maxillary sinus & T4aN2cM1 & $\begin{array}{l}\text { TM with modified neck } \\
\text { dissection }\end{array}$ & $\begin{array}{l}\text { DWD shortly after } \\
\text { surgery with sternal } \\
\text { metastasis }\end{array}$ & $\begin{array}{l}\text { Cheong et al., } \\
2014 \text { [12] }\end{array}$ \\
\hline $\begin{array}{l}18 \text { case } \\
\text { series }(15 \\
\text { cases })\end{array}$ & $\begin{array}{c}\text { Mean age at } \\
\text { diagnosis } 60.3(\mathrm{SD}, \\
\pm 21.3) \\
\text { Male } 6 \\
\text { Female } 9\end{array}$ & $\begin{array}{l}\text { Nasal cavity } 7 \\
\text { Maxillary sinus } 5 \\
\text { Ethmoid sinus } 1 \\
\text { Frontal sinus } 1 \\
\text { Sphenoid sinus } 1\end{array}$ & $\begin{array}{cc}\text { T1/2 } & 3 \\
\text { T3/4 } & 10 \\
\text { TX } & 2 \\
\text { N0 } & 9 \\
\text { N+ } & 0 \\
\text { NX } & 6 \\
\text { M0 } & 14 \\
\text { M1 } & 0 \\
\text { MX } & 1\end{array}$ & $\begin{array}{c}\text { Surgery alone } 3 \\
\text { surgery and RT } 7 \\
\text { RT alone } 4 \\
\text { No therapy } 1\end{array}$ & $\begin{array}{c}\text { Five-year disease- } \\
\text { specific survival of } \\
48.5 \%\end{array}$ & $\begin{array}{l}\text { Patel et al., } \\
2015 \text { [5] }\end{array}$ \\
\hline 19 & $66 / \mathrm{M}$ & Maxillary sinus & T3N0M0 & $\mathrm{PM}+\mathrm{RT}+\mathrm{CT}$ & $\begin{array}{l}\text { LR, DWD } 10 \text { months } \\
\text { after initial presentation }\end{array}$ & $\begin{array}{l}\text { Ando et al., } \\
2015 \text { [9] }\end{array}$ \\
\hline 20 & $78 / \mathrm{F}$ & Ethmoid sinus & T4N0M0 & Surgery + RT & $\begin{array}{c}\text { Disease-free after } 36 \\
\text { months }\end{array}$ & $\begin{array}{l}\text { Iqbal et al., } \\
2015 \text { [20] }\end{array}$ \\
\hline
\end{tabular}


TABLE 1: Continued.

\begin{tabular}{|c|c|c|c|c|c|c|}
\hline Number & Age (years)/sex & Location & Stage & Treatment & Outcome & Author, year \\
\hline 21 & $66 / \mathrm{M}$ & Maxillary sinus & Recurrence & Palliative & DWD after 12 months & \\
\hline 22 & $68 / \mathrm{M}$ & Maxillary sinus & Recurrence & Palliative & DWD after 1 month & \\
\hline 23 & $46 / \mathrm{M}$ & Maxillary sinus & T4N0M0 & Palliative & DWD after 5 months & \\
\hline 24 & $54 / \mathrm{M}$ & Sphenoid sinus & $\begin{array}{l}\mathrm{T} 4 \mathrm{~N} \text { and } \\
\mathrm{M} \text { unclear }\end{array}$ & Surgery + CT + RT & DWD after 12 months & $\begin{array}{c}\text { Liu et al., } 2016 \\
\text { [23] }\end{array}$ \\
\hline 25 & $55 / \mathrm{M}$ & Maxillary sinus & T4aN0M0 & RT & $\begin{array}{l}\text { No significant effect, } \\
\text { died } 4 \text { months after } \\
\text { initial examination }\end{array}$ & $\begin{array}{c}\text { Hasnaoui } \\
\text { et al., } 2017 \text { [18] }\end{array}$ \\
\hline 26 & $35 / F$ & Maxillary sinus & T4N0M0 & $\mathrm{PM}+\mathrm{CT}+\mathrm{RT}$ & DWD after 12 months & $\begin{array}{l}\text { Soltani et al., } \\
2018 \text { [28] }\end{array}$ \\
\hline 27 & $75 / \mathrm{M}$ & $\begin{array}{l}\text { Ethmoid }+ \text { frontal } \\
\text { sinuses }\end{array}$ & T4aN0M0 & RT & $\begin{array}{l}\text { Remained independent } \\
\text { after } 12 \text { months }\end{array}$ & Our case, 2018 \\
\hline
\end{tabular}

ND, not described; RT, radiation therapy; DWD, dead with disease; TM, total maxillectomy; RE, removal of eye; LR, local recurrence; CT, chemotherapy; PM, partial maxillectomy; FL, follow-up loss; LNs, lymph nodes.

responded to the radiochemotherapy but that was not the case with the sarcomatous component [11].

Nonetheless, aggressive treatment may not cease disease progression and improve survival. Cheong et al. [12] reported on a 61-year-old male patient who underwent total maxillectomy and modified radical neck dissection and died shortly afterwards with sternal metastasis, despite having had extensive surgery with curative intent.

Table 1 shows the similar cases of sinonasal carcinosarcoma reported in the literature [1,2,9-31]. The optimal treatment of this disease remains undetermined. It is difficult to ascertain the effectiveness of the treatment modalities (a combination of surgery, radiotherapy, and chemotherapy) from the small number of cases available in the literature. They generally confer a poor outcome and a high recurrence rate. A recent large case-control analysis of 15 sinonasal patients in America showed an average five-year diseasespecific survival of $48.5 \%$, which is significantly poorer than controls with carcinosarcoma at other anatomical sites [5]. Therefore we advocate, when patients are operatively fit with resectable disease, they should undergo aggressive surgical treatment with adjuvant radiotherapy as an attempt to improve outcome. This is because radiotherapy alone tends to convey a less favourable outcome, and the role of chemotherapy is unclear.

Since the optimal management of carcinosarcoma remains uncertain, it is intuitive to study a related but separate (also highly aggressive) entity known as teratocarcinosarcoma $[26,33-35]$. This tumour type also includes a component of neuroectodermal tissue and is much more prevalent in the medical literature. According to a recent systemic review of 49 patients, it is recommended that optimal treatment involves radical surgical resection followed by radiation therapy [25].

If more doctors are aware of this condition and the associated presenting symptoms, perhaps earlier diagnoses can be made. Therefore, patients may potentially get the option of a curative total resection, since the invasion of the skull base and surrounding structures is a poor prognostic factor.

In conclusion, sinonasal carcinosarcomas represent rare neoplasms, with aggressive character and unfavourable prognosis. Here we present a case of extensive sinonasal carcinosarcoma extending into the anterior cranial fossa and into the orbit and also a review of the current international literature regarding this rare yet aggressive neoplasm. There is currently a lack of specific guidelines on the optimal management of sinonasal carcinosarcoma, and the treatment represents a challenge for the clinicians. The key message that we would like to disseminate to our colleagues is the importance of suspicion and early detection, as well as the necessity to adopt a holistic approach when counselling patients.

\section{Consent}

The patient has consented for publication in written form.

\section{Conflicts of Interest}

The authors declare that there are no conflicts of interest regarding the publication of this article.

\section{References}

[1] J. K. Moon, A. Y. Kim, D. S. Chang, and K. Y. Park, "Carcinosarcoma of the maxillary sinus," Clinical and Experimental Otorhinolaryngology, vol. 6, no. 2, pp. 114-116, 2013.

[2] M. L. Shindo, R. B. Stanley Jr., and M. T. Kiyabu, "Carcinosarcoma of the nasal cavity and paranasal sinuses," Head and Neck, vol. 12, no. 6, pp. 516-519, 1990.

[3] J. G. Batsakis, "'Pseudosarcoma" of the mucous membranes in the head and neck," Journal of Laryngology and Otology, vol. 95, no. 3, pp. 311-316, 1981.

[4] IARC, World Health Organization Classification of TumoursPathology and Genetics of Head and Neck Tumours, IARC Press, Lyon, France, 2005.

[5] T. D. Patel, A. Vazquez, M. A. Plitt, S. Baredes, and J. A. Eloy, "A case-control analysis of survival outcomes in sinonasal carcinosarcoma," American Journal of Otolaryngology, vol. 36, no. 2, pp. 200-204, 2015.

[6] A. Cardesa, P. J. Slootweg, and SpringerLink (Online Service), Pathology of the Head and Neck, Springer-Verlag, Berlin, Heidelberg, Germany, 2006. 
[7] T. Y. Kaminota, H. Yamada, and N. Hato, "A case of spindle cell carcinoma of the hypopharynx," Practica Oto-RhinoLaryngologica, vol. 145, p. 92, 2016.

[8] O. Nappi and M. R. Wick, "Sarcomatoid neoplasms of the respiratory tract," Seminars in Diagnostic Pathology, vol. 10, no. 2, pp. 137-147, 1993.

[9] M. Ando, Y. Saito, T. Morikawa et al., "Maxillary carcinosarcoma: identification of a novel MET mutation in both carcinomatous and sarcomatous components through next generation sequencing," Head and Neck, vol. 37, no. 12, pp. E179-E185, 2015.

[10] Y. Furuta, T. Nojima, N. Terakura, S. Fukuda, and Y. Inuyama, "A rare case of carcinosarcoma of the maxillary sinus with osteosarcomatous differentiation," Auris, Nasus, Larynx vol. 28, pp. S127-S129, 2001.

[11] H. Sonobe, K. Hayashi, K. Takahashi et al., "True carcinosarcoma of the maxillary sinus," Pathology-Research and Practice, vol. 185, no. 4, pp. 488-492, 1989.

[12] J. P. Cheong, S. Rahayu, A. Halim, A. Khir, and D. Noorafidah, "Report of a rare case of carcinosarcoma of the maxillary sinus with sternal metastasis," Ear, Nose, and Throat Journal, vol. 93, no. 6, pp. E1-E4, 2014

[13] H. B. Alem and M. K. AlNoury, "Management of spindle cell carcinoma of the maxillary sinus: a case report and literature review," American Journal of Case Reports, vol. 15, pp. 454458, 2014.

[14] F. L. Ampil, "The controversial role of radiotherapy in spindle cell carcinoma (pseudosarcoma) of the head and neck," Radiation Medicine, vol. 3, no. 4, pp. 225-229, 1985.

[15] D. V. Doshi, U. Tripathi, R. I. Dave, S. J. Pandya, H. K. Shukla, and B. C. Parikh, "Rare tumors of sinonasal track," Indian Journal of Otolaryngology and Head and Neck Surgery, vol. 62, no. 2, pp. 111-117, 2010.

[16] R. Feinmesser, J. Wiesel, E. Deutsch, M. Sela, and I. Gay, "Carcinosarcoma of the nose and paranasal sinuses-a case report," Rhinology, vol. 20, no. 3, pp. 167-170, 1982.

[17] M. A. Hafiz, J. Mira, and C. Toker, "Postirradiation carcinosarcoma of the nasal cavity," Otolaryngology-Head and Neck Surgery, vol. 97, no. 3, pp. 319-321, 1987.

[18] J. Hasnaoui, S. Anajar, M. Tatari et al., "Carcinosarcoma of the maxillary sinus: a rare case report," Annals of Medicine and Surgery, vol. 19, pp. 41-44, 2017.

[19] S. N. Howard, W. R. Bond, I. S. Hong, and R. D. Foss, "Right maxillary sinus sarcomatoid carcinoma (sarcomatoid/spindle cell carcinoma)," Otolaryngology-Head and Neck Surgery, vol. 137, no. 2, pp. 355-357, 2007

[20] M. S. Iqbal, V. Paleri, J. Brown et al., "Spindle cell carcinoma of the head and neck region: treatment and outcomes of 15 patients," Ecancermedicalscience, vol. 9, p. 594, 2015.

[21] B. Lichtiger, B. Mackay, and C. F. Tessmer, "Spindle-cell variant of squamous carcinoma: a light and electron microscopic study of 13 cases," Cancer, vol. 26, no. 6, pp. 1311-1320, 1970.

[22] A. L. Lim, Z. Zahirrudin, and K. C. Pua, "A rare case of nasopharyngeal carcinosarcoma," Medical Journal of Malaysia, vol. 67, no. 4, pp. 428-429, 2012.

[23] T. W. Liu, S. H. Hung, and P. Y. Chen, "Sinonasal spindle cell carcinoma presenting with bilateral visual loss: A case report and review of the literature," Oncology Letters, vol. 12, no. 1, pp. 401-404, 2016.

[24] I. Meyer and G. Shklar, "Carcinosarcoma of the maxillary sinus; report of a case," Oral Surgery, Oral Medicine, and Oral Pathology, vol. 10, no. 10, pp. 1065-1074, 1957.

[25] P. Misra, Q. Husain, P. F. Svider, S. Sanghvi, J. K. Liu, and J. A. Eloy, "Management of sinonasal teratocarcinosarcoma: a systematic review," American Journal of Otolaryngology, vol. 35 , no. 1 , pp. 5-11, 2014.

[26] S. Mohanty, L. Somu, and M. Gopinath, "Sino nasal teratocarcinosarcoma-an interesting clinical entity," Indian Journal of Surgery, vol. 75, no. S1, pp. 141-142, 2013.

[27] A. A. Sanabre, J. Gonzalez-Lagunas, P. H. Redecilla, and G. R. Martin, "Carcinosarcoma of the maxillary sinus: a case report," Journal of Oral and Maxillofacial Surgery, vol. 56, no. 12, pp. 1456-1460, 1998.

[28] M. Soltani, P. Deyhimi, M. H. S. Najafabadi, S. Pourarz, N. A. Moghaddam, and M. Fayazi-Boroujeni, "A report of spindle cell carcinoma in maxillary sinus: diagnosis and management," International Journal of Cancer Management, vol. 11, no. 1, p. w9676, 2018.

[29] T. Terada, "Pure sarcomatoid carcinoma of maxillary sinus and nasal cavity simulating malignant fibrous histiocytoma," American Journal of Clinical Pathology, vol. 135, no. 1, pp. 128-131, 2011.

[30] T. Terada and T. Kawasaki, "Spindle cell carcinoma of the nasal cavity," International Journal of Clinical Oncology, vol. 16, no. 2, pp. 165-168, 2011.

[31] S. Viswanathan, K. Rahman, S. Pallavi et al., "Sarcomatoid (spindle cell) carcinoma of the head and neck mucosal region: a clinicopathologic review of 103 cases from a tertiary referral cancer centre," Head and Neck Pathology, vol. 4, no. 4, pp. 265-275, 2010.

[32] S. Gupta, D. Santoriello, R. Wieczorek, and M. D. De Lacure, "Spindle cell carcinoma of the nasal cavity," Rare Tumors, vol. 5, no. 10, pp. 38-40, 2013.

[33] S. Chakraborty, A. R. Chowdhury, and G. Bandyopadhyay, "Sinonasal teratocarcinosarcoma: case report of an unusual neoplasm," Journal of Oral and Maxillofacial Pathology, vol. 20, no. 1, pp. 147-150, 2016.

[34] D. J. Kurmi, R. S. Mittal, A. Sharma, A. Gandhi, and S. Singhvi, "Sinonasal teratocarcinosarcoma involving nasal cavity, nasopharynx, and all paranasal sinuses with bilateral orbital and intracranial extension: a rare case report," Asian Journal of Neurosurgery, vol. 12, no. 2, pp. 232-240, 2017.

[35] M. Sable, A. Kakkar, K. Garg, and V. Suri, "Sinonasal teratocarcinosarcoma: an underdiagnosed entity posing diagnostic challenges," Turkish Neurosurgery, vol. 27, no. 3, pp. 468-471, 2017. 


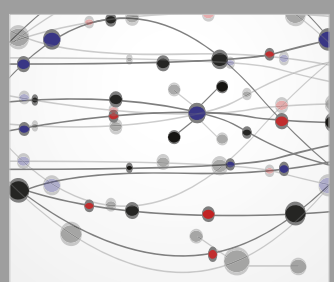

The Scientific World Journal
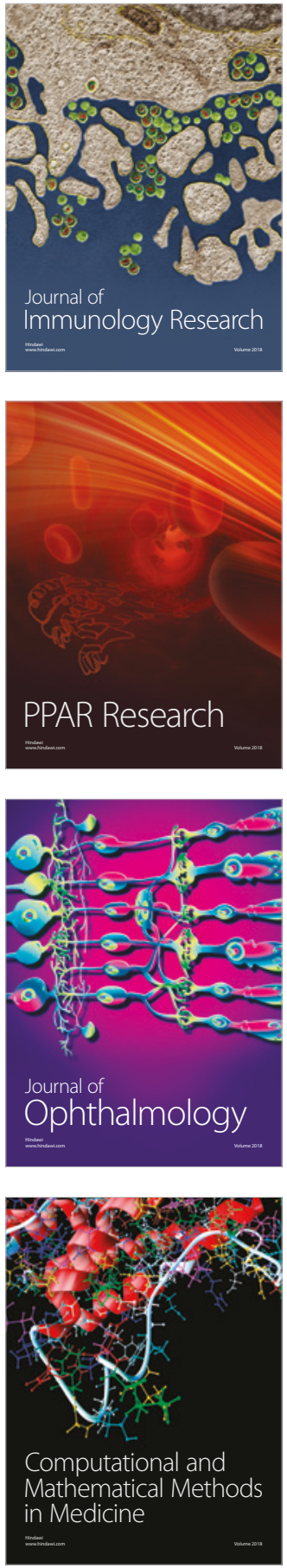

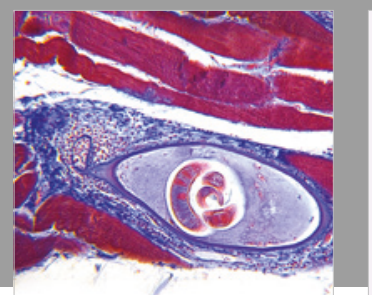

Gastroenterology Research and Practice

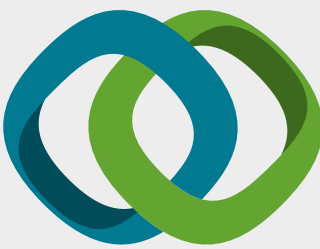

\section{Hindawi}

Submit your manuscripts at

www.hindawi.com
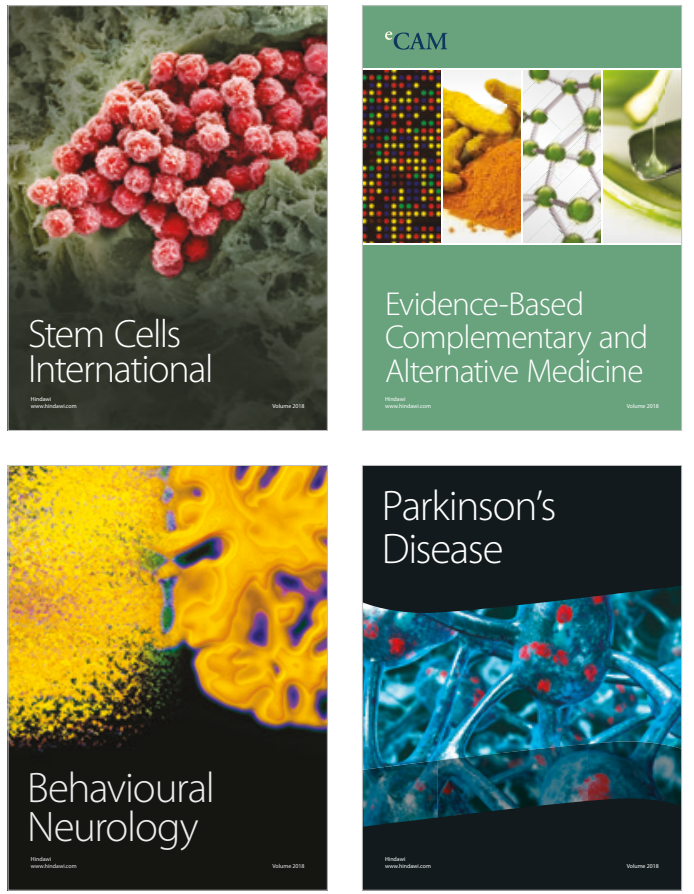

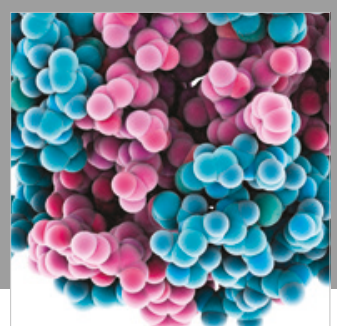

ournal of

Diabetes Research

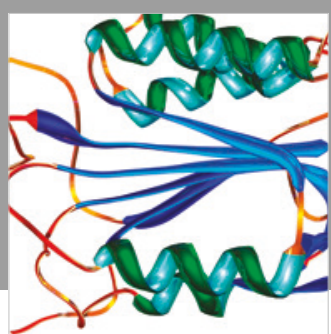

Disease Markers
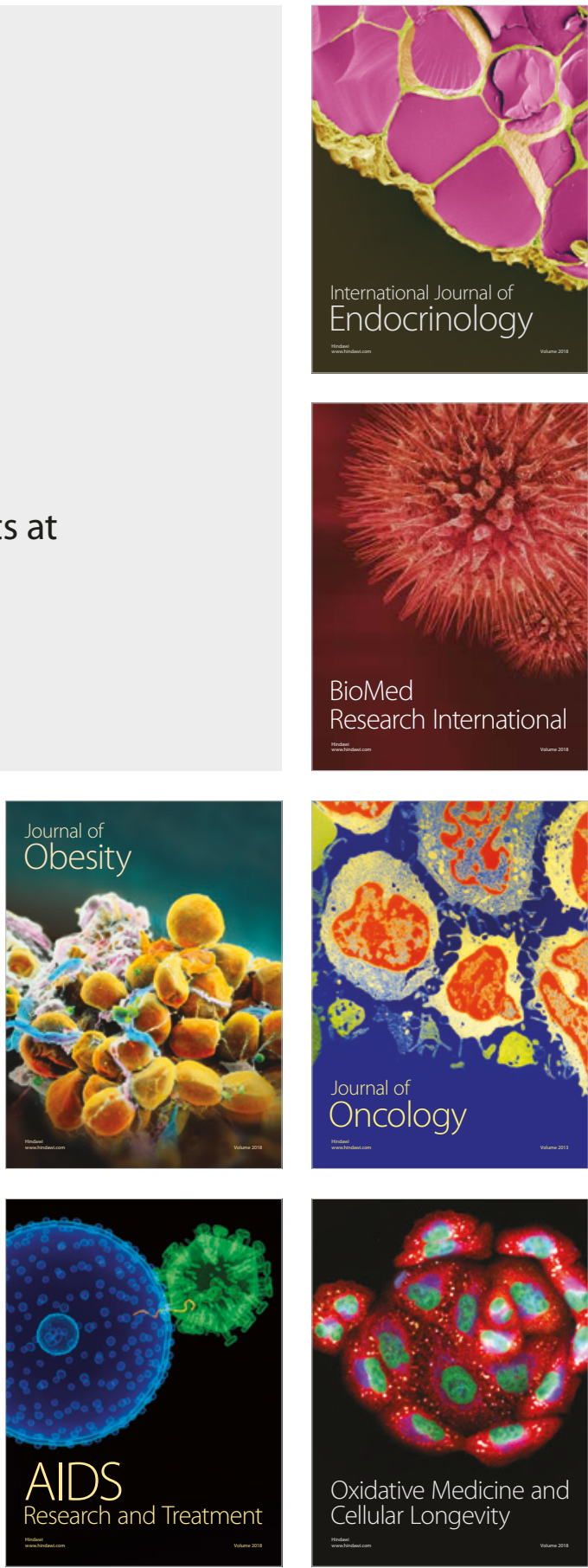